Sunniva Evjen, Associate professor, Department of Archivistic, Library and Information Science, Oslo Metropolitan University, suev@oslomet.no

Tonje Vold, Associate professor, Department of Archivistic, Library and Information Science, Oslo Metropolitan University, tonjevo@oslomet.no

\title{
"It's all about relations" - an investigation into the youth librarian's role and proficiency
}

\begin{abstract}
Developing library services for children and youth is a challenge for the library community. Statistics show that while younger children are avid library users, their usage often wanes as they grow older. Norwegian children between the ages 9 and 15 visited the library half as much in 2017 as they did in 1991 (SSB 2017). One exception is Biblo Tøyen, Norway's only library dedicated to children between the ages 10-15. Recently named Library of the Year, the library provides a very popular space for its target group. Based on a qualitative study consisting of participant observation and interviews with members of the library staff, who are not trained librarians, this paper highlights the staff's varied contributions to establishing Biblo as a third place and developing the participatory elements of the library. We look at what guides the staff in facilitating specialized programming for the users and how they perceive their own their role as library staff by exploring in what ways they have interacted with, learnt from, guided and "policed" the target group in developing a participatory, third-space atmosphere. Our findings suggest that the staffs' relational capacity is vital for creating a successful library space for this age group. From our study, we propose that the multi-aspect role of the youth librarian as teacher, confidante, inspirer, parent, and guardian needs to be taken into serious account in the future education of librarians and for the development of future youth libraries.
\end{abstract}

Keywords: public libraries, children's libraries, librarians, librarianship, tweens, third place, participation

\section{Introduction and problem statement}

Children and youth's access to entertainment, knowledge, culture and education is facilitated by many different sources and through a wide range of technologies. When former hierarchies of quality and mediation falter, and entertainment is no longer seen as contrary to learning or quality (Hvenegaard Rasmussen \& Jochumsen, 2010; Juncker, 2006; 2011) it affects how we consider library services for children. In this situation, libraries may feature a kitchen, a makerspace, and a stage and cooperate with many different non-library stakeholders. Many libraries recruit staff who are not trained librarians, preferring staff with varied backgrounds and skills. Furthermore, the ideal of user participation within library development has become prominent since its coinage in 2006 (Lankes 
\& Silverstein). It is often referred to through the catch-phrase "from collection to connection" and used in relation to the increasingly common transformation of libraries from serious places for solitary studies into fun places for social activities.

The library's focus on activities and entertainment is, however, just one aspect of what connection and participation entails. "A nation is democratic to the extent that its citizens are involved, particularly at the community level" (Hart, 1997). Strengthening library users' participation reflects an understanding of democracy in which involvement is a core component. In 1979, the UN's Convention on Children's Rights underlined children's right to participation as fundamental for securing their position in society. Here, participation is understood as "the process of sharing decisions which affect one's life and the life of the community in which one lives. It is the means by which a democracy is built, and it is a standard against which democracies should be measured. Participation is the fundamental right of citizenship" (Hart, 1997). From this perspective, the library is one place where children may influence decisions affecting their lives in the local community. It can provide them with a space for enacting their citizenship, experiencing democracy and themselves as part of a larger society, and ultimately also a space for empowering them. At the same time, libraries are adults' workplaces. Their involvement in guiding or overruling children's involvement will in turn affect the level of children's participation. Therefore, more knowledge is needed about how youth librarians approach and carry out their professional role and responsibilities.

This article explores the library staff's work methods and self-perceptions through interviews with employees and observations conducted at the Oslo inner city library branch Biblo Tøyen, which is open only for children and youth between 10 and 15 years - we use the informal terms children, youth and "kids" interchangeably, as it is difficult to find one label. This age group is considered particularly difficult to create library services for, as they are too old for story-telling and too young for many adult activities (Pisarski, 2014). At Biblo, none of the employees are professionally trained librarians and we refer to them using the terms library staff or staff member(s). However, we use the term librarianship when discussing the practices of those working at Biblo as their work is important for informing library practice.

Through a case study where the boundaries of librarianship are particularly unclear, we try to elicit the different roles the library staff take on and how the staff understand their work with mediation, programming and user relations, as well as how to they interpret the library they have developed.

We have focused our attention on two aspects of librarianship, which will be further presented in the section on theoretical perspectives. The first concerns the third place (Oldenburg, 1989) and the second, the participatory library (Lankes \& Silverstein, 2006). For this article, participation is seen in context of the library as a space and the extent that the staff can promote empowerment, belonging and trust within that space.

We pose the following research questions:

What is the library staff's contribution to developing the library into a third place and what implications does the creation of a third place have for youth librarianship?

How does the library staff contribute to a participatory library and how can we understand their emphasis on empowerment?

The findings have relevance for a sustained focus on relationship building in library education and for how we understand the role of youth librarians.

\section{Background}

Since it opened in 2015, Biblo Tøyen has become widely recognized as a successful library. Markers of its success include receiving the Library of the Year award in Norway and having been nominated for several international library awards. The number of visits to Biblo is consistent and high. Most importantly, the library has become an 
established youth-only hangout in a multiethnic, inner-city community with severe socio-economic challenges and a high degree of child poverty. Biblo's success makes the library a valuable case for developing our understanding of best practices in youth librarianship.

The staff at Biblo have created their own work methods, possibly more so than in other libraries. They were all employed at the same time and were given freedom to set up and define Biblo, which invited and allowed for a fair amount of creativity and ingenuity. Hence, the library staff's task was twofold; to set up the library and to staff it - to make Biblo Tøyen happen. In a sense, the staff acted as library entrepreneurs by having had to develop their own professional role(s) as Biblo, the "product", was tested and adapted.

The birth of Biblo Tøyen has come about at a time when there has been much professional reflection and discussion on how libraries can best respond to the needs of youth. The meaning of space, place and materiality for children's lives (Holloway \& Valentine, 2000; Horton \& Kraftl, 2006; Sæther \& Seim, 2018) and their participation in society (Seim, 2018) have gained substantial attention. In the same period, the Scandinavian library field has encouraged more dynamic and less hierarchical modes of mediation and literary culture, as well as promoted children's participation. The Danish report Children's future library service (Brandt \& Paulsen, 2008) recommended that the library should offer media experiences across different types of materials and genres within a physically appealing library space. Children's needs, including participation, were made the focal point of library service development and their multimodal competences were acknowledged. The report notes that children's lives today are heavily organized by parents and adults and only when they are 10 years of age and older do they begin to explore their own interests and activity preferences (2008, s. 13). Accordingly, the public library community has adopted new perspectives on children's library services. One example is the Dutch Library of 100 talents (Mosch \& Bertrams, 2009), which provides a space where the children actively engage in developing the library services and programs. As expression and learning go beyond the written or spoken word, the library recognizes how for example sound, motion, molding, and colour are vital when developing experiences, culture and learning in different children. The library space accommodates this philosophy, and the children have taken active part in shaping it. Another well-known library with a bottom-up approach is TioTretton in Stockholm, Sweden. It opened in 2011 and welcomes tweens from 10 to 13. The library is based on the target group's own wishes for a library space - a place of their own, where "grown-ups knew what they were talking about, but weren't teachers" (Bayliss, 2015). As will be discussed, the design and running of Biblo Tøyen can be seen to have encompassed and put into practice much of the current thinking on youth librarianship

\section{Previous research}

The role of a professional librarian has been the subject of extensive research and scholarly work; however, there has been less focus on the role of a children's or youth librarian. There is, however, a body of research concerned with library services for these age groups, which has relevance for understanding youth librarianship.

Beth Juncker distinguishes the public library for children (children's library) from the school library. While school libraries are part of the educational sector and meant to support learning in a classroom context, the children's libraries are - at least in Scandinavia - part of the cultural sector. Influenced by aesthetical philosophy and culture theory, cultural expressions are likely to be interpreted and mediated differently in children's libraries where leisure, personal interest, and play matters more than in an educational context (2011). In the field of education, where principles from pedagogy and learning theory reign, school libraries have other priorities. Moreover, the professionalism in these two sectors differ (2011). Their challenges in the knowledge and experience society are similar - but their solutions may not be the same.

One scholar who has investigated the child librarians' self-perception is Barbro Johansson (2010, p. 28). Librarians describe themselves as different from parents and teachers, as a "different kind of adult", "an adult who is there but for whom one does not have to accomplish anything", "someone to ask questions one doesn't dare to ask one's parents", and "part of the social security-net". Together with Frances Hultgren (2018), Johansson has also studied participation at Malmö stadsbibliotek. During their observations, they found that parents or teachers 
accompanying children to the library tended to regulate children's behaviour in ways that the librarians might not, thus confirming the idea of the librarian as "a different kind of adult" and the library is "a different sort of space".

Johansson and Hultgren underline that developing methods that operationalize concepts like participation and empowerment, at the same time as providing children with space, are crucial tasks for the child librarians' professional role. To create a physical space for children within the library implies that the space is created and formed by those who use or visit it (Johansson \& Hultgren, 2018, p. 21; Rydsjö et al. 2010). Therefore, a review of ongoing practice is necessary if the goal is to reach out to larger groups of children. Hedemark (2012) concludes that traditional reading promotion in schools and libraries focuses on printed books. From interviewing groups of children, she observed that this emphasis in reading promotion does not necessarily invite new users into the library. This type of promotion speaks to children who already like to read. Libraries need to consider children's current reading experiences and habits - their "multi-literacies" - if the goal is to reach out and include a larger audience.

In a historical analysis of the development of teen library services in the US, Shari A. Lee identifies three ideological approaches to library services that have existed, co-existed and competed: 1) The library as an institution that promotes reading, 2) the library as an educational institution and 3) the library as an institution that serves to advance society by uplifting the underserved (2014; Walter \& Meyers, 2003). These differing ideologies have formed librarians' understanding of their work and, subsequently, the types of services teens have received. In the early 1900s, the library reformer Samuel Sweet Green advocated "in every library a friend of the young, whom they consult freely when in need of assistance, and whom in addition to the power of gaining their confidence, has knowledge and tact enough to render them real aid in making selections" (Lee, 2014). An increase in youth library use came about in the 1930 s and 40 s as a result of a brief focus on community betterment and education, which preceded libraries' adoption of various business models and a market demand model for mediation of reading material. Lee suggests that the many problems US libraries face in getting teens to visit the library can be linked to the perception that libraries are not accommodating enough for the teens to stay; they prefer nice bookshops, libraries focus too narrowly on reading promotion, and teens experience libraries as "uncool" places and librarians as hostile. Furthermore, she notes that personal relationships with the librarians are lacking. Lee points out the general low prestige teenagers have in US culture and warns that library professionals, especially those who do not usually work with this group, may reflect these attitudes. She purposes that libraries need to support teens' developmental needs and asserts that if supported by their communities, teens will support their communities too: "This requires supporting the needs of the entire person instead of primarily focusing on homework and pleasure-reading needs, which is the model to which many libraries still subscribe".

Lee also observes the need for more research on teens and libraries to build knowledge (2014). A scholar who has tried to fill this gap is Åse Kristine Tveit (2016). Her dissertation Rom for barn (2016) investigates children's library services in Norway at the time when they first proliferated (1914-1935) compares it with in a present-day perspective (2000-2015). She concludes that the objective of public libraries' services for children were quite clear in the former period - to keep children off the street by providing meaningful and useful literature and activities in the library. Consequently, the librarian became an authority figure, a custodian of the library collection, but also a literary guide and a protector figure for the children coming to the library. The objective of children's library services today seems less obvious. However, she observes that there is a consensus in the library community that children should be involved in developing both library space and services. The librarian has maybe lost some authority but keeps on being a guide in the world of literature.

\section{Theoretical backdrop}

To understand the work at Biblo Tøyen, it is relevant to look at it within a certain framework. A key concept for our research is the third place. Coined by sociologist Ray Oldenburg (1989), the third place is conceptualized as something other than the home or work place, it encompasses the community arenas that help develop relations 
between people and serves as hubs or spaces that welcomes citizens in - at little or no cost. The criteria for the establishment of a third place includes a neutral ground, a convenient location in a local community, where people can come and go. It is a place without socio-economic barriers, where conversation is the main activity. It has a low profile and unassuming appearance. The mood is playful, there are food, drinks and games there. Finally, it provides a "home away from home" where the people coming has a sense of ownership.

The second key concept is participation and as a continuation, the participatory library. Participation is often discussed and promoted in relation to concepts of democracy, as our introduction pointed out, and empowerment. For the youth librarian empowerment must be put in the context of childhood. Johansson sees empowerment as a continuum (2010) on which it can be understood in respect to 1) the individual child or 2) children as a group.

1) The individual child. Empowerment is seen as something that brings about emancipation, a value. This is the "therapeutic position" in which the adult provides information for the child, but the child, independently, chooses what to do with the information s/he receives; thus, the adult regulates the child's empowerment. This is what Johansson calls the "market-oriented position".

2) Children as a group. Empowerment is seen as the facilitation of children's formations, such as the formation of a (political) group. Children's group interests are addressed, as well as their position in a hierarchy where old age has privileges. According to Johansson, this is "empowerment as establishing counter power". In this case, empowerment works to question all categories and views hierarchies and power imbalances as things that are in constant change and that fluctuate from situation to situation.

The participatory library was coined by Lankes and Silverstein in 2006. The term added to the already established term Library 2.0 (Fichter, 2006), which was defined through a formula: (books'n'stuff + people + radical trust) $x$ participation. For Library 2.0 to work, a high level of trust between library staff and library users is required, for example trusting users enough to let them help develop the library catalogue. Lankes and Silverstein thought the Library 2.0 term was unclear. Their concepts of participatory libraries and participatory librarianship maintain a technological focus and include digital preservation of what is co-created in a library. "Knowledge is created through conversation", Lankes \& Silverstein writes, and the libraries are important places for community conversation. Nguyen, Partridge and Edwards (2012) further investigated the participatory library, moving beyond the technological aspects. They identify five features of the participatory library that affect participation: technological factors, human factors (librarians and users), educational factors (of the staff), socio-economic factors, and environmental factors (atmosphere in library). Hvenegaard Rasmussen (2016) adds to the understanding of the participatory library by describing the different forms of participation that can take place in a library, without a singular digital focus. They include volunteer programs, interactive displays, workshops, co-creation, user driven innovation and book clubs.

Both the third place and participation are part of the Biblo's agenda. Being a third place in the neighbourhood is a stated goal for the library. In accordance with Biblo's agenda, the participatory elements have been present from the start. The youth were involved in planning the library and creating the library system. Their efforts have been realized and today the library is a space where the youth can make and create, as well as meet and engage with their peers; thus, it can be said that Biblo supports a high degree of user participation and has many aspects of a third space. In our research, we have looked at both trust and participation, to see how the staff at Biblo work to develop the participatory elements of the library and how they work towards developing it as a third place.

\section{Research design}

This article draws on data collected through the research project PLUSii Tøyen (Vold \& Evjen, 2016), a case study that dwells on the development of the Tøyen libraries with the backdrop of rapid urban development in the same areaiii. Observations and interviews with stakeholders, staff and library users make up the main methods of data collection. 
Interviews with staff members were conducted the winter of 2017 and 2018. They were semi-structured in the sense that we had prepared the main topics that we wanted to address, but otherwise the interviews were carried out as conversations. The interviews were recorded and partly transcribed. We analyzed the data with a bricolage strategy (Kvale, 2007), where we followed different approaches to obtain relevant perspectives for the discussion.

To ensure anonymity, the informants are not named in our presentation of the findings and direct quotes are not linked to any personally identifying information. The quotes from the informants were translated to English for this article. The original Norwegian quotes are available upon request.

Taking "success" as a point of departure, does not mean that we as researchers are not critical or embody the needed distance to those interviewed. Rather, it gives us the possibility to investigate what the library staff themselves regard as success factors. A consistent narrative emerged from our interviews with members of the library staff. In the following section, we have singled out elements in this narrative: The beginning, the setting, the characters, the values and the action. Each of these elements are constitutive of the others, yet in the discussion, we want to propose that relationship building is the single most important factor in the success-story of Biblo.

\section{Findings}

1) The beginning: learning and adapting

All narratives have a start and, from the interviews, this narrative begins with the importance of the first months at Biblo. All the staff members talk about how the lessons from a difficult start guide them today and are part of what makes the library succeed. Hence, to understand their current self-perceptions, roles and challenges, we need to investigate their stories of what happened:

In the start we didn't know what we were. We didn't know our users; they didn't know us. I have always thought that it was like some kind of UFO landed at Tøyen. Completely alien. With a lot of lights, the doors open, and then they arrive, the Mars-men. We were them. It was demanding in the beginning, but we also learned a lot, and above all that it's all about relations.

If we look at the start in more detail, there are several points that the interviewees identify as problematic. The first was the idea that freedom was to reign inside the library. One staff member relates: "The manager was clear; it will be a library. But how can it be a library if children are running around, screaming? Looking back, we shouldn't have had a big party as a start-up-event. It sent the wrong signal."

In addition, there were episodes of violence making the space unsafe: "We had to establish rules and make contracts. Those who accepted could stay. Only then it was possible to establish Biblo as a space." The library staff highlight the importance of establishing user guidelines and predictable and efficient sanctions for the library to become a good place for kids. Those who were excluded for bad behavior could only re-enter after bringing their parents to meet the staff. The safety of the majority had to come first. The staff emphasize the importance of regulating the space, making it safe and welcoming, and not just inspiring or fun. Addressing the social issues has been a pretext for doing the fun things: "..Now we've won the space back and control it, so we can start doing all the things we had in mind when we started here".

The staff at Biblo had a lot of freedom in creating the library. One staff member, however, underlined that s/he felt that the Biblo staff had benefited from sharing the workspace with experienced librarians from a nearby branch library in the period before the opening of Biblo: "We got advice and help from the ladies [librarians] there. They know everything about the library systems, acquisition, how to meet users, how to settle various situations." The Biblo staff still had a lot that they had to figure out on their own. Another staff member distinguishes between "the place itself and library stuff ", saying "None of us have worked in a library before, 
none has worked in a place like this before, but neither has anybody else. So [...] they can help us with library stuff, but not with the place itself."

The Biblo staff was motivated by meeting neighborhood kids prior to opening, observing the need for a new space: "They behave totally different, there was no library culture among the kids, and we managed to settle the situation ok". They got a feeling of the community at night, too and saw how the kids "ran the plaza at night" through use of violence and bullying, making "a complete hell. And I thought, 'shit, is this where we are going [to have the library]?'"

From the first months of trying, failing and improving, the staff developed norms and guidelines for how to go about their work, which was expressed as "everything we do should benefit the space". But what does that entail? For the staff, it meant to work on relations with the users, to gain trust. Staff members also talked about what Biblo is and what the staff does as an "attitude", and that they together are creating an "atmosphere".

\section{2) Setting: Using the space, welcome and de-territorializing}

In the narrative of Biblo's success, the staff members all highlight the setting. The main factors are: How can and should the space be used, who can use it for what, what is the best atmosphere?

The ideal of "doing what benefits the space" is operationalized in several ways. If we take "the space" in the most literal sense, it concerns how the library space is used to make the users "feel welcome" and "safe". One example is the staff greets everyone who comes in. The information desk is located near the entrance and is always staffed. One staff member explains: "the positioning of the information desk is really a peace-keeping mission. Everyone is seen and greeted by name. It is a transition to the library." All staff members put effort into remembering names: "The way we greet the children affects their experience of the space. Learning their names is very important, so we try to do that". Greeting the library users as they arrive also provides them with an opportunity to voice their concerns: "If anyone wants to say something, they have the opportunity when they arrive. We want to do things in ways that helps them understand that we are there for them."

Doing what benefits the space also implies regulating the use of the space. Biblo's interior is developed to inspire kids to participate in activities (kitchen, maker-spaces, board games, paint), to sit in solitude, or to socialize (Vold \& Evjen, 2016). The kitchen at Biblo is described as "the heart" where there is always something going on, both planned activities and informal "hang-out". If they have a popular activity at the kitchen, the staff may arrange a parallel Minecraft session to prevent the kitchen area from being overly congested and to ensure that all users have activities to participate in.

In addition, no single group should take complete ownership: What benefits the space is also that "no one - and everyone - owns it". The children who visit Biblo come from different backgrounds. The regulars live in the neighborhood, but kids come from all the schools in the community and some from other parts of the city. The staff members want the local library users -those coming from the immediate community - to feel a sense of ownership of the library, but they do not want it to lead to exclusionary behavior. Instead of forcing the local children to share what they may feel belongs to them, the staff encourage the children to feel pride in the library and their neighborhood: "Some territorial issues have occurred. When this happens, we intervene and say "hey, you guys from Tøyen have this library, but others like it and they want to come here so it is your job to show them around."

\section{3) Values: Participation and empowerment}

From a democratic perspective, participation and empowerment are vital for developing children's libraries and involving children in library development is a stated goal (see for example Brandt \& Poulsen, 2008). At Biblo, local children were involved in various stages of planning and were also invited to classify the collection before the opening (Vold \& Evjen, 2016). How are these values adhered to in the Biblo narrative? 
All staff members see "participation" as a goal, but underline the value of participation as empowerment, and not for the actual project per se: "We talk to the library users a lot. The most important thing for us is that they feel they have been heard. So even if it doesn't always benefit the projects, we try to involve them, let them have a say." The staff member explains that this is not easy and sometimes the staff members unintentionally influence the children. However: "they should feel they contribute. It is important because that's what they will do later in life - contribute, not just be passive subjects to what others decide".

Through the interviews, it surfaces that participation, in the sense that children decide what to do, is not a straightforward ideal. One staff member explains:

We are pretty good at knowing what they want, but we won't give them exactly that, rather something they didn't know existed. It is "failed participation" to just give them what they want. It has to do with kids and education. Someone must show you the world. There is an infinite number of things and cultural expressions and exciting stories and fantasies.

Identifying professional values does not mean that these are always prominent in the everyday practice. A staff member says there is "very little participation" at Biblo, referring to the HoMaGo-model: Hanging out, mess around, geek out (Ito et al., 2009). In his opinion they have established the hanging out, while mess around happens sometimes. Geek out is rare, but happens, and is what he wants more of. For this staff member, success in participation happened when children realized that the 3D-printer could be used to make fidget spinners, which became a local "craze". The library staff's role in this was simply to supply enough material. Planning and production were taken over by the kids and fulfilled needs only they knew that they had. From this perspective the infinite numbers of stories and fantasies emerge out of participation, not the other way around:

"When they own it, it changes totally, turns into something else. Then we lose control. It is very giving. But it doesn't happen often. It is something I wish to work more systematically towards because if we work with activities as simply entertainment it takes place on a "superfluous" level, but with this there is so much potential to master, and to feel ownership. To work with this model opens for more consciousness about participation and that children have more to say about what a library is."

\section{4) Characters and relations: "Safe adults"}

If the staff members will "show kids the world", it follows that their worldview and how they connect with the kids is important. Building relations is regarded as paramount by the staff and guides their work methods: One says: "[they need to] have somewhere they can ask questions, where they meet adults who are neither teachers or family, who they can talk to - this is maybe a bit diffuse, but there is an "atmosphere", "attitude" here". Another says: "It is very important. [...]. The kids see that we are different. We have the same rules, but different ways of understanding and connecting with various children." They tell us children come specifically to meet the staff.

Establishing close relationships with the users does not mean that the staff members cease to act as guides or educators. From our observations, we see how a fair amount of the communication is of educative kind. One example is of a boy who tossed paper on the floor. He was not simply told to pick it up and throw it in the bin, but explained that the cleaning personnel do an important job in our society and that deserve respect. The staff is

important mediators of culture and books. For children who have reading difficulties, contact with adults is very important for obtaining knowledge, even if the children are unaware of it. To talk with us is to open something unrelated to school. We have become the third space. Many are here from the time we open until the time we close.

Also, the staff appears as "playful" and "a bit crazy" - it is part of how they make themselves interesting for the kids: for instance, when a Dutch delegation visited, all the staff members spoke Dutch that day, even if they didn't know the language. 
Relations are personal and demands that the staff get involved. One of them says:

I think it is extremely important that we are personal. The children open up to us so we should do the same. But, we have different approaches: some maintain 'this is a job' and have a kernel that is closed off'. But I think if the kids open up to me, I must be able to do the same. Then they respect me. And, they must believe that I mean what I say. That it comes from the heart. They want to take part in activities because we do. It is essential.

For some, like this staff member, it is ok to continue the relationships with the kids outside the library, for example by taking someone to the cinema or an event.

How do the staff members regulate these relations? One staff member says: "They understand that we are not their friends, but we are still their friends, it's fluid." They stress their responsibility to be grown-ups the kids can talk to and to be supportive and understanding if some of the children are having a hard time at home or at school. It is a challenge to leave at the end of the day and simply forget about your work when they know kids have problems. However, they experience their work and relations as meaningful: "To be a safe adult, I take comfort in that. Children know they can enter here and no matter what's happened, they can talk to us about it."

\section{5) Action: Programming and reading (participation and empowerment)}

Do events make Biblo a success story? The staff agrees that the first year of programming was too ambitious. The productions were high quality, high cost, and demanded a high level of concentration from the participants, but in the end they did not work. The staff recalls inviting well-known authors for book talks, which the kids found boring. One staff member remembers a particular episode when an author got angry and said the kids were not ready. "We learned: we can't have that." The staff now focuses on relatable experiences intended to empower the kids, not deflate them: "We want them to feel mastery of what they do and strengthen their selfesteem. No one likes to feel overrun or misunderstand. We must start with something that's a bit familiar. Give them a "lifebuoy" to cling to and then we can push them further ashore. If it is out of their grasp, you accomplish the opposite of what you want."

Another important lesson concerns predictability. To encourage participation, the children need to trust the people who are invited into the library to hold events or be involved in the programs offered. This means that "pop-up-arrangements" rarely work. Artists or others who drop in, do their thing and leave give little value. This does not "benefit the space". A couple of examples illustrate what the staff members prefer:

The first one started after the world-renowned author Andy Griffith visited, and talked about his popular books about the boys in the multistory treehouse. The idea of treehouses remained, and the staff provided tools and material and the kids were invited to make their own treehouse in the library. No plans for the design of the treehouse were drawn up; the children simply added and removed elements along the way. A second example was a student who came to the library to teach kids sewing. She had to postpone her project until she had been present in the library for a couple of weeks. At this point, she had become a predictable part of the space and the group. Once she had established herself as part of the group, she was able to start her sewing course. At the end of the project, the kids felt safe and free enough to show off their clothing designs on the catwalk. This would not have happened if she had just walked into the space and started her course, according to one informant.

The staff maintain predictable programming with a weekly "menu" of set activities, which can be adjusted by small measures instead of having too many one-time activities. One example is how the weekly cooking sessions can be given themes that brings in other dimensions to a practical activity. One time, the topic was "borders and walls", and focused on national dishes with more than one origin (e.g., ceviche in Peru/Chile) or food as a sustainability issue (e.g., scampi, salmon). 
Success is not measured in numbers at Biblo. As one of the staff puts it: "We don't have mass activities. There is normally from one to seven participants, but those who join in have a high-quality experience. Few things appeal to all, what matters is that those who take part in an activity have a good experience."

Because of the experiences from the first period of programming, the staff knows that the users are not accustomed to attending this type of programming and events. Thus, empowerment at Biblo entails teaching kids what it means to listen, to participate, and to experience arts and culture in different settings:

Many of them are not used to people reading aloud to them [..] They haven't been to concerts or plays from when they were five years old. A lot about culture also concerns being comfortable in such settings. Without experience, you will feel like an alien in a theater hall. We can be a place where they can obtain experience.

As already pointed out, the staff emphasize the children's need to feel safe to participate. "We must establish contact first. They need to trust us and feel comfortable here and, once that is established, it is crucial to provide opportunities that can expand their experience." This also affects how the staff go about designing library programs and how they regard their roles in the library: "Predictability" and "Trust" are key. While Biblo's interior brings associations of fun and entertainment, there is no belief in "acute entertainment" among the staff. The ideal brought to the fore by many of the staff members is that the kids "own" what is going on and that they "take something away from it".

Although there are few "class room-like" activities, many kids want help with homework. The staff help and once a week a math tutor is available. The staff observes great variations in skills. One of them has realized that some of the kids can barely read. He feels for the kids who bring long lists of general demands from teachers when they struggle to make it through one single page. Here, promotion of literature is pointless: "They don't want us to recommend a book in that situation!". The book collection at Biblo is relatively small and handpicked by youth librarians from other branch libraries is Oslo (Vold \& Evjen, 2016), and is not among the aspects of which the staff has had to develop themselves. The staff members note the diversity of their users' interest in reading: there are many children who read nothing and stay 'all day while other children come in only to return books and borrow new ones.

This means that promotion of literature must happen in different ways. "Guerilla-reading" is a tactic used by the staff, which involves reading aloud while the kids do other things, such as baking or working on other projects. One staff member expresses concern that there is too little book promotion at Biblo and believes they need someone who knows how to arrange exhibitions. "The books on the shelves don't move. What circulates are the books where covers are visible." Another relates that some kids just realize after a while that "wow, there are books here too!". The staff members explain that loan figures are quite low and that they feel some pressure to increase them, but it is not clear how to go about it.

\section{Discussion: Old Bildung in the new, relational library}

When we listen to the story told by the staff members at Biblo, the findings suggest that Biblo comes close to serving as a third place. This leads us to our research question:

What is the library staff's contribution to developing the library into a third place and what implications does the creation of a third place have for children's librarianship?

Our findings show the complexity of the staff's daily work, as well as the particularities existing within the Biblo Tøyen context. A recurring topic in the interviews was how the staff work to "benefit the space" and Biblo as a third place.

Summing up Oldenburg's criteria, a third place is a neutral ground, a convenient location in a local community, where people can come and go. It is a place without socio-economic barriers, where conversation is the main activity. It has a low profile and unassuming appearance. The mood is playful, there are food, drinks and games there. Finally, it provides a "home away from home" where the people coming has a sense of ownership. 
Previous investigations of the extent to which the libraries match the third-place criteria have been inconclusive or only partly affirmative (Aabø \& Audunson, 2012; Eikeland, 2007; Ljødal, 2005), but there is no doubt that public libraries do hold some of the inherent features of a third space, such as being "neutral ground", acting as a leveler, and being accessible.

The Biblo staff work in several ways to make the library function as a third place and, in the interviews, the concept of "third place" is referred to as a specific goal. Learning the children's names and making everyone feel welcome in the entrance area contributes to creating a welcoming atmosphere. The mood is playful and the staff focus on establishing an atmosphere that makes it easy for the kids to feel secure and free. Playfulness and fun are not just games or interior, but that the staff members are funny too, as seen in the example of speaking "Dutch". Their efforts to provide the kids with something new involve how they communicate and use their personas.

How free people are to come and go at Biblo is debatable. The guidelines for behavior at Biblo have excluded some but are considered necessary to create a safe space. There is a common understanding that these guidelines are essential for Biblo to develop as a third place. The social issues at the library must be addressed before the activities and events can take place. The social context must be taken into account in the establishment of the library as a social space and the social issues at the library must be addressed before the activities and events can take place.

In general, there is a very close connection between the staff members' conception of the library space and their conceptions of their role(s). In this context, it is interesting to ask whether the relatively low focus on reading comes from the books as part of the interior, and not something the staff has been involved in picking out. By contrast, the kitchen is described as the "heart of the library". The kitchen comes with several values attached to it when the staff describes its functions: it is social, it is an arena for learning, it concerns cultural heritage, it allows for deep conversations, and it provides nutrition.

The local connection is important. Many of the children feel a sense of ownership to their neighborhood hangout. To avoid territorializing, the staff need to step in and regulate behavior so that the library space remains "neutral". For instance, they focus on pride and ownership as positive, yet place the responsibility on the children to reach out to newcomers and show them around. Similarly, the mantra of "doing what benefits the space" ensures that the neutrality of the space is protected from anyone who misuse its openness.

This leads us to our second research question: How do the staff members contribute to a participatory library and how can we understand their emphasis on empowerment?

The staff members relate that they seek to involve and empower children, which is reflected the management's goals. However, the staff members see problems with this ideal. It is difficult not to influence the children. All the interviewees point out the importance of not giving kids what they want, which could work against empowerment. If we return to Johansson's ideas on empowerment, does Biblo Tøyen focus on the individual child or the collective? Do they focus on the therapeutic, market-oriented or political aspects of empowerment?

The interviews show that the staff fluctuate between various positions. They want to cater for the group as a whole: they want the marginalized among the users to take pride in their community, become confident consumers of culture, and expand their horizons. Thereby, their approach is in line with the ideas and recommendations that Lee (2014) promotes in the US context: to work for the whole person. The staff members build personal relationships, they do not have negative notions of their user group, they help the user groups with their development needs, and they have a strong sense of working within and for the community.

The way the staff members work at Biblo is through a high-intensity method that focuses on the individual child. Learning their users' names and their individual stories are examples of how they focus on the individual child. The fact that activities are perceived as successful based on the quality of each child' experience and not on the 
number who attend is another example of the focus on the individual. These findings suggest a resistance towards empowerment in the form of a "market-oriented position" (Johansson, 2010). Promoting "status quo" is not what the staff wants. Rather, they aim to broaden the users' horizons, hence more in line with seeing empowerment in emancipation terms.

Hedemark (2012) found that focusing on traditional reading promotion in libraries can alienate children who are not big readers. At Biblo, the challenge seems to be opposite: their broad conception of learning and focus on participation leaves less room for books and literature than the staff would prefer. The lack of trained librarians has surely led to new approaches and a fresh outlook, but it also means that the role as guide in the world of literature is at present secondary at this library.

In light of these findings, the Biblo staff come close to voicing the ideal of Bildung, that education in every sense of the word is uplifting: Their aim is to show the children what the world is and to expand their horizons. This is also connected to a perspective on (many of the) the kids as deprived; not only economically, but also culturally. They lack a basic cultural education many other kids take for granted. In Johansson's interrogation of how children's librarians try to fulfil their own role description, she focuses quite narrowly on the way librarians (and teachers) promote reading and literature (2010). However, Bildung in the Biblo context is not achieved through reading, but is linked to arts and culture. Empowering the children entails giving them confidence in themselves as users of culture.

Facilitating participation has also shown how important it is for the staff to "control the space". The staff's approach is not authoritative, yet by enforcing rules, regulating activities, and "doing what benefits the space", the staff members have adopted, to some degree, the role of the traditional authoritative children's librarian. Freedom at Biblo is not the absence of regulations, but the presence of the right ones.

To be "a different kind of adult" (Johansson, 2010) is a priority at Biblo, but in a different sense of the word. To be a bit "crazy" and "playful" can be seen as being a different kind of adult - and as part of their role as library staff. As in Johansson's case, the Biblo staff want to be someone the children can ask about anything, beyond book requests and schoolwork. Opening their own life to the kids is part of the conception of their staff role or 'librarianship' at Biblo, as well as an ethical engagement.

Accordingly, David Lankes has addressed the topic of librarianship with a broadened sense of what this role entails. In his view, it is not the library that provides the services people need or want, but the librarians. It is not enough to simply provide a service - Lankes says "to be a librarian is not to be neutral, or passive, or waiting for a question. It is to be a radical positive change agent within your community" (Lankes, 2016). The staff at Biblo act as change agents in the Biblo context. They work towards social goals, but are not social workers, they want to educate the kids, but they are not teachers, and they use learning and cultural expressions to engage the youth, thereby bringing something new to the community. It seems the stability and familiarity characterizing Biblo's programming contributes to change - likewise the level of trust between the staff and children. The result is children who trust the staff and enjoy being with adults. We believe this is crucial for building trust with the broader society, in which children and youth are placed in a hierarchy below adults. Biblo shows how librarians could be agents who enable children to enact their citizenship, see themselves as part of a larger society and experience democracy, thereby empowering them.

\section{Conclusion}

In our study, we find that Biblo does not only exemplify a participatory library, but a relational one. Working to establish good and trustworthy relations is significant when the staff describe their work. Furthermore, the case of Biblo shows the importance of the library staff engaging with users on a personal level. Knowing the children and understanding their lives is necessary to serve and cater to their cultural and informational needs. Also, trust between staff and users seems necessary for a participatory practice. 
The relevance for library practice is clear: Our study shows that the success of Biblo is related to the library staff's ability to develop and maintain relationships with children. This finding has implications for librarianship and the teaching of librarianship. Relationship building is not included in Library and Information Science coursework but should be acknowledged as an important aspect of "children's librarianship". User relations are important in any library, but perhaps particularly in children's libraries where trust forms the basis of participation and belonging. The staff's role in promoting literature is less visible at Biblo and some of our informants admit this aspect is missing. However, the role as guide in a world of culture is apparent, as well as the role as teacher. The staff members describe a very conscious way of weaving bits and pieces of learning into both everyday activities and overall programming.

Biblo is unique, as the staff has remained unchanged since the opening. The likelihood of eventual staff turnover puts into question how the current culture at Biblo will endure. Will the Biblo culture survive such changes? And, do the results at Biblo infer that a library needs employees as "entrepreneurs" to succeed or can the Biblolibrarianship be taught and learned? This is still unknown, but there currently exists a Biblo library culture that the staff and users have negotiated and formed, and keep on forming, together.

\section{References}

Aabø, S., \& Audunson, R. (2012). Use of library space and the library as place. Library \& Information Science Research, 34(2), 138-149.

Bayliss, S. (2015). Over 13 not admitted. In: Rebecca T. Miller \& Barbara A. Genco (Red.), Better Library Design: Ideas from Library Journal (p. 88-89). Lanham: Rowman \& Littlefield.

Brandt, A.E., Poulsen, A.K..(Red.) (2008). Fremtidens biblioteksbetjening af børn. [The future library service of children]. København: Styrelsen for Bibliotek og Medier.

Cuong Nguyen, L., Partridge, H., \& Edwards, S. L. (2012). Towards an understanding of the participatory library. Library Hi Tech, 30(2), 335-346.

Eikeland, M.C. (2007). Fjerdestedet : folkebibliotek som møteplass i lokalsamfunnet. [The fourth place: the public library as a local meeting place]. Oslo: Høgskolen i Oslo.

Fichter, D. (2006), Web 2.0, Library 2.0 and radical trust: a first take. [Blog]. Retrieved from http://library2.usask.ca/ fichter/blog on the side/2006/04/web--2.html

Hart, Roger (1997). Children's participation: the theory and practice of involving young citizens in community development and environmental care. New York: UNICEF.

Hedemark, Å. (2012). A Study of Swedish Children's Attitudes to Reading and Public Library Activities. New Review of Children's Literature and Librarianship, 18(2), 116-127.

Holloway, S. L., \& Valentine, G. (2000). Spatiality and the new social studies of childhood. Sociology, 34(4), 763783.

Horton, J., \& Kraftl, P. (2006). Not just growing up, but going on: Materials, spacings, bodies, situations. Children's Geographies, 4(3), 259-276.

Hvenegaard Rasmussen, C. (2016). The participatory public library: the Nordic experience. New Library World, $117(9 / 10)$, 546-556.

Ito, M., Baumer, S., Bittanti, M., Cody, R., Stephenson, B. H., Horst, H. A. \& Perkel, D. (2009). Hanging out, messing around, and geeking out: Kids living and learning with new media. Cambridge: MIT press. 
Jochumsen, H., \& Hvenegaard, C. (2010). Från läsesal till levande bibliotek: Barn, ungdomar och biblioteksrummet. [From reading rooms to living libraries] In: K. Rydsjö, F. Hultgren \& L. Limberg (Red.), Barnet, Platsen, Tiden: teorier och forskning i barnbibliotekets omvärld (p. 213-240). Stockholm: Regionbibliotek Stockholm.

Johansson, B. (2010). Barnbibliotekariers och forskares barnperspektiv. [Perspectives on children from researchers and children's librarians] In: K. Rydsjö, F. Hultgren \& L. Limberg (Red.), Barnet, Platsen, Tiden: teorier och forskning i barnbibliotekets omvärld (p. 23-50). Stockholm: Regionbibliotek Stockholm.

Johansson, B. \& Hultgren, F. (2018). Att utforma ett barnbibliotek tillsammans med barn: Delaktighetsprocesser på Malmö stadsbibliotek. [Developing a children's library with kids - participatory processes at Malmö city library] Borås: Høgskolan i Borås. Retrieved from: http://hb.divaportal.org/smash/get/diva2:1182398/FULLTEXT01.pdf

Juncker, B. (2006). Om processen: det æstetiskes betydning i børns kultur. [About the process: the importance of aesthethics in children's culture] København: Tiderne skifter.

Juncker, B. (2010). Barns bibliotek - nya villkor, nya utmaningar, nya teorier och begrepp. [Children's libraries new terms, new challenges, new theories and new concepts] In: K. Rydsjö, F. Hultgren, \& L. Limberg (Red.), Barnet, platsen, tiden: teorier och forskning i barnbibliotekets omvärld (p. 241-270). Stockholm: Regionbibliotek Stockholm.

Kvale, S. (2007). Doing interviews. London: SAGE.

Lankes, R. D., Silverstein, J. L., Nicholson, S., \& Marshall, T. (2007). "Participatory Networks: The Library as Conversation" Information Research, 12(4) paper colis05. Retrieved from http://www.informationr.net/ir/124/colis/colis05.html

Lankes, R. D. (2016). The new librarianship field guide. Cambridge: MIT Press.

Lee, S. A. (2014). Beyond Books, Nooks, and Dirty Looks: The History and Evolution of Library Services to Teens in the United States. The Journal of Research on Libraries and Young Adults.

Ljødal, H. K. (2005). Folkebiblioteket som offentlig møteplass i en digital tid. [The public library as a meeting place in a digital age] ABM-utvikling.

Mosch, M. \& Bertrams, K. (2009). Library of 100 Talents - Heerhugowaard, Netherlands. 75th IFLA Conference and Council. Milan. Retrieved from https://www.ifla.org/past-wlic/2009/103-bertrams-en.pdf

Oldenburg, R. (1989). The great good place: Café, coffee shops, community centers, beauty parlors, general stores, bars, hangouts, and how they get you through the day. New York: Paragon House Publishers.

Pisarski, A. (2014). Finding a place for the tween: Makerspaces and libraries. Children and Libraries, 12(3), 1316.

SSB. (2017). Kulturbarometeret 2016 [The Culture Barometer]. Retrieved from: https://www.ssb.no/kultur-ogfritid/artikler-og-publikasjoner/ attachment/308555? ts=15c118b8418

Seim, S. (2018). Hvilken betydning har rom og sted for barn og unges deltakelse i barnevernets praksis? [What is the role of space and place in children and youth's participation in social service practice?] In: O. Sæter \& S. Seim (Red.). Barn og unge: by, sted og sosiomaterialitet (p. 199-221). Oslo: Cappelen Damm.

Sæter, O., Seim, S. (Red.). (2018). Barn og unge: by, sted og sosiomaterialitet. [Children and adolescents: city, place and sociomateriality]. Oslo: Cappelen Damm. 
Tveit, Å. K. (2016). Rom for barn: Norske barnebibliotek i perioden 1914-35 og på 2000-tallet [A Space for Children: Norwegian Children's Libraries 1914-1935 and in the 21st Century]. Oslo: Høgskolen i Oslo og Akershus.

Vold, T., \& Evjen, S. (2016). How children find their way: Access, adaptability and aesthetics in the organisation and design of a new children's library. Proceedings of the Association for Information Science and Technology, 53(1), 1-9.

Walter, V. A. \& Meyers, E. (2003). Teens \& Libraries: Getting It Right. American Library Association.

\footnotetext{
i A space for children

ii Public Libraries in Urban Space

iii PLUS Tøyen is part of the ongoing ALMPUB project, financed by the Norwegian research council's KULMEDIA program.
} 